Pobrane z czasopisma Annales N - Educatio Nova http://educatio.annales.umcs.pl Data: 26/04/2023 06:27:18

DOI: $10.17951 /$ en.2019.4.39-55

\begin{tabular}{lcr}
\hline & ANNALES \\
& UNIVERSITATIS MARIAE CURIE-SKŁODOWSKA & \\
LUBLIN - POLONIA & \\
VOL. IV & SECTIO N & 2019 \\
\hline
\end{tabular}

Keiji Sato

University of Hokkaido, Japan

ORCID ID: https://orcid.org/0000-0001-5753-815X

keiji_sato@hoku-iryo-u.ac.jp

\title{
The Introduction of Reformation of Liberal Arts Education for Dental Students: A Case Example of Health Sciences University of Hokkaido
}

Wprowadzenie działań reformatorskich dotyczących edukacji w zakresie przedmiotów humanistycznych dla studentów stomatologii na przykładzie badań własnych na Uniwersytecie Nauk Medycznych Hokkaido

\begin{abstract}
Summary: In general, liberal arts education for medicine/dental students tends to decline across the world. One of the main reasons is that current liberal arts educational system does not always adapt to the changing social needs and most students do not feel the necessity of mastering liberal arts subjects. This paper presents the case of dental school of Health Sciences University of Hokkaido in Japan, analyzes the most ideal concept of liberal arts education (that is currently being implemented), and demonstrates our reform efforts in liberal arts education.
\end{abstract}

Keywords: liberal arts; English education; Japan; school of dentistry; soft skills (competency) 


\section{INTRODUCTION}

Health Sciences University of Hokkaido (hereinafter referred to as H.S.U.H.) is a university of health care sciences with 6 faculties and 9 departments which cover odontology, pharmacy, nursing science, social welfare studies, rehabilitation science, medical technology and psychological science. The top educational priority of H.S.U.H. across these faculties and disciplines, likewise other private universities, is to raise the pass rate of national vocational exams for current students and keep its high level. Improper educational policy and ineffective measures lead to a reduction of the pass and employment rates. Furthermore, public exposure of the results might lead to a decrease in the number of applicants for admission to university. Therefore, fulfilling educational program for national vocational exams and bringing its fulfilment to the public's attention gives a profound impact on strategic management of university.

In addition, the reason why state exams' preparation is more and more concerned is the increase in the difficulty level of exams of health care professions as a whole. For example, the pass rate of pharmacists has changed from $88.31 \%$ (2012) to 79.1\% (2013), 60.8\% (2014), 63.2\% (2015), 76.9\% (2016), 71.6\% (2017), and $70.6 \%$ (2018) (Website of the Ministry of Health, Labour and Welfare, 2018a). In the meantime, that of dentists - 71.1\% (2012), 71.2\% (2013), 63.3\% (2014), 63.8\% (2015), 63.6\% (2016), 65.0\% (2017), and 64.5\% (2018) (Website of the Ministry of Health, Labour and Welfare, 2018b). The main cause of the difficulty setting is to improve the quality of medical professions as well as to control worker redundancy in future. Under such circumstance, students, who must inevitably become overly sensitive about their future employment, are likely to avoid studies that are not directly linked to state exams and focus entirely on revision of the exams as a best choice for promising future. Besides, considering the key numbers, pass rate of state exams, employment rate and number of candidates registered for the entrance exam to university, students' parents as well as university staff are likely to support ideas to increase and enhance revision of state exams while decreasing the number of non-medical specialized subjects. As a result, it may naturally come out an idea of phasing-out of liberal arts subjects.

In reality, however, all parties are not in favour of placing "state-exam-supremacism" as a core of university curriculum because it may narrow students' future vision/perspective. Additionally, they may ignore pursuing other important factors and focus on immediate benefit. As regards parents, they hope their children will master techniques and get medical certifications as well as stand on their own feet as "a person with a great personality" through education. As 
for university staff, we must establish and maintain the most ideal 4-year and 6-year educational institutions based on "academism," not as a simple vocational training center. Then, this article, featuring the case of dental school that faces the most severe state exam issue among our 5 facilities, illustrates the result of students' questionnaires, refers to the importance to learn non-dental specialized subjects and discusses the most ideal and effective format to implement liberal arts program for students. The reform movement of liberal arts education is also related to enhancing skills of students who admit to oversee training program as a prime target.

\section{IMPORTANCE OF LIBERAL ARTS SUBJECTS FOR HEALTHCARE PROFESSIONALS AND STUDENTS}

\section{Ambiguous definition of "liberal arts education" in Japan, $k y \bar{o} y \bar{o}-k y \bar{o} i k u$}

Liberal arts education is translated into Japanese as kyōyo - kyōiku which includes quite an ambiguous expression, kyōyō. Kyōyō as a meaning of liberal arts must be combined with a word of kyōiku ("education"). Kyōyo as a single word includes various meanings such as "accomplishment", "civilization", "breeding", refinement and so on. Youichiro Murakami, referring to Bushido, one of the tokens of the Japanese traditional samurai spirit, explained that kyōyo is manifestation of moral value not to stick to own knowledge, experience and specialty, but to have depth as a person (Murakami, 2004, pp. 21-28). Furthermore, Kinnya Abe mentioned that kyoyo is a power not to carry water for administration or authority but to stick to own principles to change society (Abe, 1997, p. 180). Such a vague definition of kyōyo is, unfortunately, quite common in Japan and directly gives negative influence on the concept of liberal arts education, kyōyo - kyōiku. Hiroshi Segi explained the importance of liberal arts education as the development of ability to track down a core problem and deal with it by a proper method (Segi, 2015, p. 55). In addition, he described that cultural sciences included in philosophy, non-fictious literature and arts and proficiency of the sciences helped to develop our cognition and imaginary skills (Segi, 2015, p. 32). Both explanations mentioned above hardly lead us to invent a concrete principle and direction to make "a person with a great personality" and organize curriculum of liberal arts education. Shizuo Asogawa denied the Japanese concept of liberal arts as a foundation for character formation and criticized that rich knowledge promotes a feeling of superiority, condescending expression and a hostile feeling to others (Asogawa, 2015, pp. 20-22). 


\section{Background of liberal arts education in Japan}

Since the Meiji Restoration in 1868, Japan had introduced European and American educational system, students used to learn liberal arts for "character-building" under old-education-system high school and then stepped up to old-system University to expertise in each field (Karube, 2007, pp. 166-167). After the defeat of Japan in WW2, the occupation by General Headquarters of the Allied Forces and the dissolvement of the Empire of Japan, the University Standard, the so-called "Daigaku Kizyun", was implemented in 1947 to enhance the development of human resources which hold more democratic and Western moral value (Karube, 2007, p. 167). However, Shigeru Nanbara, the school master of Tokyo Imperial University and main author of the "Standard", did not have a concrete idea about the contents of liberal arts education, regardless of its pre-eminent importance (Karube, 2007, p. 172).

Current system of liberal arts education is partially based on "The Outline of Standards for establishment of Universities" that was projected by the then Ministry of Education, Science, Sports and Culture ${ }^{1}$ in 1991. According to the "Outline", general education course, which had provided liberal arts education for first- and second-year students at most Universities, was abandoned. One of the most disputable parts of the former educational system is that although it did not enough prove the scholarly linkage between liberal arts education and specialized education, students could not advance to the next grade without obtaining the required credit for liberal arts subjects (Recommendation of Liberal Arts, 2013, p. 9). For this reason, students could hardly find value to take these courses, and philosophy and other subjects that were representative studies of liberal arts had been gradually reduced. Once philosophy, ethics, literature and art had occupied major status which should be mastered for intellectuals and reflected on the intellectual level of that person, they have lost integrative powers among all subjects because of specialization and segmentation in each science field in recent years.

Although most universities widely accepted the "Outline" and abolished the name of kyōyo - kyōiku, only one university in Japan (Tokyo Medical and Dental University) has maintained the general education course as a sort of liberal arts education as of 2018. According to the website of the University, the aim of general education course is to develop the following skills: (1) wide $k y \bar{o} y \bar{o}$ (cultural accomplishment) and sensibility to understand yourself and

1 The Ministry was renamed the Ministry of Education, Culture, Sports, Science and Technology (MEXT) in January 2001. 
others as a member of civil society; (2) constant learning skill to consider, comprehend and track down issues scientifically; (3) communication skill for acting as an international medical specialist; and (4) basic academic skill, thinking power and technique for the coming specialized education (Website of Tokyo Medical and Dental University, 2018). Firstly, one of the problems of the system is that general education course is finished just within the first year and there is no time to make students achieve and develop the above-mentioned 4 skills. Secondly, although it promotes interexchange among different faculties to mingle various studies and diverse people through liberal arts education, its effect is limited because the University consists of just two faculties of healthcare sciences; medical school and school of dentistry. Thirdly, most of liberal arts classes are those of natural science such as biology, chemistry and statistics. It gives impression that the liberal arts education is just the first step of medical specialized education.

The three points described above are not only a problem at Tokyo Medical and Dental University but at any other universities. This situation demonstrates that even Tokyo Medical and Dental University, which is a leading figure of Japanese liberal arts education, has faced the limitation of realization of real liberal arts in educational institutions. Through our history, even Japanese intellectuals do not have any clear concept of liberal arts, kyoyō, so it is natural that we cannot provide any useful educational program to students. As a result, decreasing of necessity of liberal arts education is moving ahead.

\section{Insufficiency of liberal arts education at H.S.U.H.}

H.S.U.H. does not yet officially present clear vision concerning liberal arts education. In the 2018-2019 curriculum, school of dentistry has 111 lectures, 66 of them are dental specialized ones and 45 are general ones. Due to including interdepartmental subjects, 45 general lectures have various subjects which do not concern dentistry. Nevertheless, the general lectures are mostly related to topics of healthcare sciences such as medical ethics, biology, bioethics, and so on. If the lectures are more subdivided by the theoretical concept, 12 are foreign languages lectures, 3 are communications lectures and the rest are subjects which emphasize the linkage to medical sciences such as medical sociology, medical anthropology, and medical economy. Unfortunately, there are no subjects such as history, art, literature and music theory except a course of international relations. Obviously, the system for achievement of real liberal arts education of our University is far from sufficient one. 


\section{Case of the U.S. toward liberal arts course}

To plan the reform of liberal arts education system in a global context it is necessary to find out the conditions and tendencies in the area in other countries. For instance, we will consider what principles medical educational institutions in the Unites States have in order to realize most effective education and what kind of attributes they expect for medical graduates to achieve during educational terms, compared to such actual conditions concerning liberal arts education in Japan.

Internet website "the Conversation" described that medical students must master ethics, leadership, policy, economics, sociology and psychology as basic studies and do effort to understand the complex clinical micro- and macro-systems in which their patients live and work (Why Get a Liberal Education..., 2016). In addition, healthcare professional must fully understand social structures such as class, gender and race that mold both how they make medical decisions and how patients receive their care. The article stressed that they cannot be effective communicators with a sense of cultural humility without such specific training. Debra Schwinn explained that the main aim of a liberal arts education is seen as fostering insight, understanding, imagination, and discovery which may be achieved through study in communication, the humanities, social sciences, and natural sciences (Schwinn, 2016). Without doubt, these all areas are quite fundamental and inevitable for medical professionals who must have the capacity to express themselves well and listen to patients, appreciate cultural differences, understand the historic and dynamic forces behind our societal institutions. Terry Stratton, Carol Elam and Michael McGrath, referring to the Wabash conference proceedings, noted that staff of medical schools valued the following cognitive and non-cognitive qualities in applicants: (1) fluency in the scientific language; (2) intellectual curiosity; (3) research experience contributing to creativity; (4) collaborative learning skills; (5) cultural sensitivity; (6) lifelong commitment to learning; and (7) self-confidence (Stratton, Elam, \& McGrath, 2003, p. 59). At the same time, liberal arts colleges assist their graduates in development of these aforementioned skills and attitudes. As the other scholars likewise, they put emphasis on the development of specific skills to understand patients. They said that liberal arts graduates were more interested in the practice of psychiatry than their classmates from comprehensive universities because psychiatrists must understand the biological, psychological, and social components of illness, they treat the "whole person" assisting in the adaptation of individuals coping with stress, crises, and other problems (Stratton, Elam, \& McGrath, 2003, p. 61). Since the majority of patients likely prefer a dentist to be friendly and talkative (Bare \& Dundes, 2004, p. 1174), communication skills is one of the key elements. 
With regard to the above, it can be concluded that in the United States, liberal arts and general education, unlike in Japan, have a clear vision what attributes students need and what training they should take to achieve them during school years. So, this concept is quite useful to implement reform activities of liberal arts education at H.S.U.H.

\section{RESULTS OF QUESTIONNAIRES}

Issues of educational system, academism and correct cognition of liberal arts education are far from their practical life for the majority of students. If we seek their views on these issues, not a few students may provide responses like "liberal arts are irrelevant and useless for me", "I cannot find any meaning why medical graduates must take humanities lectures" (Nakajima, Tanabe, Morikawa, \& Kato, 2006, p. 120,124). Then, this section, analyzing the results of conducted questionnaires about ideal liberal arts education, seeks out what is their image of it and what they expect from the University to achieve the most idealistic educational program. Here the data from two different groups is mainly used to understand this issue from two different points of view.

\section{Case 1: second-year dental students}

The first case collects data from all second-year dental students who are obliged to take English reading-writing lectures (English C/D). Unlike first-year students, who are still new in studies, most of them already get acclimated in student life and are aware of state qualifying exam for dental profession. Unlike fourth- and fifth-year students, they are not yet busy with preparation for the exam. At the same time, they have a few liberal arts lectures and must focus on dental subjects. Here we discuss collected 69 responses to Question 1: "Is it necessary for dental students to take lectures on liberal arts courses?" and Question 2: "Is it necessary for dentists to be familiar with international affairs and foreign languages?” (Table 1).

Table 1. Opinion of students on liberal arts education and international knowledge in 2018

\begin{tabular}{|c|c|c|c|c|c|c|}
\hline Necessary & $\begin{array}{c}\text { Rather } \\
\text { necessary }\end{array}$ & $\begin{array}{c}\text { Rather } \\
\text { unnecessary }\end{array}$ & Unnecessary & Others & Total \\
\hline Q1 & $\begin{array}{c}52 \\
(75.4 \%)\end{array}$ & $\begin{array}{c}6 \\
(8.7 \%)\end{array}$ & $\begin{array}{c}2 \\
(2.9 \%)\end{array}$ & $\begin{array}{c}6 \\
(8.7 \%)\end{array}$ & $\begin{array}{c}3 \\
(4.3 \%)\end{array}$ & 69 \\
\hline Q2 & $\begin{array}{c}57 \\
(82.5 \%)\end{array}$ & $\begin{array}{c}9 \\
(13.0 \%)\end{array}$ & $\begin{array}{c}1 \\
(1.5 \%)\end{array}$ & $\begin{array}{c}1 \\
(1.5 \%)\end{array}$ & $\begin{array}{c}1 \\
(1.5 \%)\end{array}$ & 69 \\
\hline
\end{tabular}

Source: Author's own study. 
According to the result of Q1, 84.1\% of students were aware of the importance of liberal arts education. In the part of free description, many of them, however, do not describe clear reasons for the necessity of liberal arts education such as: "for expanding view", "for increasing conversation topics", or "for being useful somehow in future." These descriptions are expected to reflect on general public thought toward kyoyo which has been explained in the part of ambiguous definition of $k y \overline{o y} \bar{o}-k y \bar{o} i k u$, so we cannot accept their positive response to liberal arts education. First of all, University teachers must discuss and firm up the concept, and provide students with correct understanding of liberal arts education.

Just 3.0\% of students thought unnecessary to take liberal arts courses during dental education. As expected, most of them put priority on complete dedication to dental subjects and the coming state exam. Another remark - "inefficiency to master liberal arts subject by too-short-teaching-hours" - is worth considering. Because of the general reform of higher education, conducted according to the "Outline", the number of lectures on liberal arts and languages has drastically decreased. In most of faculties, except linguistic and English literature, the language lecture is provided just once a week. It is impossible to achieve foreign language skills by attending an 80-minute lecture once a week. Because of limitation of teaching hours, we must consider offering various types of lectures at which students need to use English skills. Therefore, other liberal arts lectures, which require foreign language skill, compensate the lack of language lectures.

While Q1 refers to the issue of students' present and near future, Q2 concerns the distant future. The result of Q2 shows that $95.5 \%$ of students think that it is important to know about international affairs and to have a good command of a foreign language. The number of positive responses to Q2 is higher than that of Q1 because most dental students recognize the importance of knowledge of foreign languages and international affairs although they cannot afford to study (except dental science now). As regards Q2, among the reasons for providing positive answers ( $22.7 \%$ of them), there were mentioned actual condition of the development of Japanese society and the importance to provide smooth medical treatment to foreign patients who have different language and cultural background. Some of the respondents gave the real example that he/she needs such knowledge to cope with reality because many foreign patients visit the dental clinic run by his/her parents. $21.2 \%$ of the respondents noticed the importance to get the up-to-date information on dentistry and to communicate with foreign scholars and dentists in the same field. One student decided to master his/ her knowledge and to become knowledgeable about international affairs due to future possibility of working and opening his/her own private dental clinic 
in a foreign country. It can be stated that the answers to Q2 are more concrete when compared to answers given to Q1.

\section{Case 2: first-year dental students attended an optional lecture on "International relations"}

This case referred to a unique group of first-year dental students who attended an optional lecture on "International relations". As they had just completed high school education and had not yet taken full-scale dental subjects, most of them did not delineate a picture of their future. Unlike the case 1, they are interested in subjects which are not completely related to dental subjects and chose the lecture on international relations. That is why, all 15 enrolled students clearly expressed the importance of liberal arts education for dental students and the necessity of wide interest in foreign languages and affairs. Since they explained its reasons, it is worth presenting their replies as follows.

The first category refers to opinions about personality formation:

- "high ethical standards", which are integral part of medical professions, have been consolidated by various types of liberal arts subjects,

- medical professions require knowledge of liberal arts subjects which includes diverse principles in order to create a trust-based relationship with patients. To be sympathetic to patients, they should have a strong sense of humanity and it is considered desirable to be familiar with other fields outside their specialty,

- the approach that it is "enough to know only medical subjects for medical professions" definitely has a negative impact on work of that person. Curiosity about various subjects results in enrichment of his/her human attractiveness,

- the importance of learning a foreign language might have been declining due to the development of IT. However, the attitude to mastering a foreign language is related to curiosity to know different cultures and nations through language. Then, it also helps to understand other people.

The second category refers to the opinions on the attainable knowledge and techniques:

- even in sports classes one can learn teamwork skill which is required in the current medical market,

- when medical professionals need to conduct difficult treatment, they must talk to their patients. In such a case, certain attitude to the patients is necessary. Such conversation skills can be developed by liberal arts education, 
- high communication skills means not only an excellent way of expression but the skill of giving good impression as an intellectual. Without it, medical professionals cannot get esteem from others. Liberal arts subjects cultivate this type of communication skills.

The third category refers to the opinions about widening views:

- liberal arts courses provide an excellent entree to a new perspective,

- viewpoint of dentists on medical issues is different from that of pharmacologists and that of non-medical professionals. We can understand various views and opinions though liberal arts education.

These comments give us a useful suggestion in order to promote the reform movement of liberal arts education. Responding to such opinions and expectations, the University authorities must effectively assemble an educational program to develop students' competences.

\section{H.S.U.H. APPROACH TO ACHIEVE EFFECTIVE LIBERAL ARTS EDUCATION}

The results of questionnaires demonstrated that first- and second-year dental students are highly motivated to take liberal arts lectures. In the current situation, however, the school of dentistry cannot afford to increase the number of teaching hours and teaching staff in order to conduct such classes. Therefore, we must focus on the improvement of existing liberal arts lectures by different means. As a matter of first priority, it is necessary to make sure what kind of skills students should achieve from liberal arts education.

\section{Necessary skills}

Liberal arts in the Middle Ages, that formed the foundation of current higher education, were composed of seven subjects: grammar, logic, and rhetoric (trivium); and arithmetic, geometry, the theory of music, and astronomy (quadrivium). Especially, trivium was the minimum and the most significant skills for the then intellectuals to enrich logical thinking, persuasiveness, and the ability to express oneself to be a leading figure among the people. This aspect shows one of the most remarkable points that liberal arts education did not aim for personality formation, being a good person, or inheritance of educational tradition but for the achievement of practical and immediately available skills. Especially, if intellectuals wanted to be rulers, mastering of trivium was indispensable. Considering it as a core matter of liberal arts education, we must provide quite a practical and useful educational framework to students. Therefore, if the 
society has changed, the skills demanded should also be changed. We should traditionally inherit original intent of liberal arts education from ancient Greece. Then, this section, following the above-mentioned American concept, discusses what skills and attributes dental students need in modern society and future working places.

\section{A. Communication skill}

Students mostly expect to achieve communication skills in liberal arts education. Especially, it is indispensable to smoothly communicate with patients. At H.S.U.H. now there is a course to learn communications with patients before starting clinical practice. However, this course mainly aims at providing medical professionals with words and attitudes that should be used during face-to-face contact with the patients. Such words should not harm the patients' feelings, whereas the attitudes should give a good impression. This is a sort of a course which aims at learning one's neutral expression, and not the method to attract others. So, we need to organize to enhance students' communication skills by using different methods. We should assign tasks to work in groups and promote more dialogues and discussion among students during lectures.

\section{B. Presentation skill}

Most of Japanese are not good at delivering public speech and Q\&A style dialogue. Presentation requires an attractive and persuasive manner of expression as well as well-prepared materials and effective use of the visual materials in front of others. As Japanese poorly perform presentations in the Japanese language, students prefer mastering their presentation in English. If they feel comfortable to deliver the speech in Japanese, those who are not able to do it in the same way might feel disappointed. If they master presentation in English, it might be much easier to use this experience during the presentation in Japanese. Lectures in English or Japanese should be the occasion for mastering short and long speeches and for explaining the process of making presentation.

\section{Discussion skill}

Most Japanese perform poorly in terms of discussion, too. Discussion needs a persuasive skill and ability to read other people's minds. With regard to (A) and (B), we must devote enough time to develop a general speaking skill.

\section{Writing (grammar) skill}

Good writing skill is also of significant importance. Students should master English and Japanese writing skill at academic level. 


\section{E. Leadership and teamwork}

Modern dental treatment is not an individual work but sometimes it requires teamwork. Whenever dentists act in the medical team, regardless of small clinic or big hospital, they often face the necessity to take leadership and organize teamwork. Dentists must give proper and easy-understandable instructions to other medical staff such as hygienists and dental technicians. Through group work, that includes various types of people, students should learn how to become the leader of the group and achieve high performance of team members.

\section{F. Basic knowledge of humanistic and social sciences}

The knowledge of business science, economy and jurisprudence is necessary to deal with socio-medical issues: jurisprudence helps to resolve claims and court cases from patients; business sciences and economy assist hospital management. Also, one of the merits to achieve knowledge of humanistic and social sciences is to smooth interpersonal relations. For instance, if medical professionals have a profound knowledge in the art field, it helps them to communicate with patients with artistic attainments at the time of consultation to help them to feel more comfortable. At the same time, an artistic interest helps to realize the importance of cozy interior of (waiting) room and the layout of medical examination in order to eliminate the unnecessary concern of patients. As mentioned above, humanistic and social studies help not only to understand patients who have various backgrounds but they also help to create efficient and effective hospital environment.

\section{G. Reorganizing of existing lectures}

University's current curriculum contains such lectures as "Overseas Training $\mathrm{A} / \mathrm{B}$ " and "Overseas Practice A/B" which encourage our fourth-, fifth- and sixth-year students to undertake practical dental training at overseas partner universities and medical institutions ${ }^{2}$ for $2-3$ weeks (Table 2). One of the most actual problems with conducting the lectures is to receive complaints from our partners because of low communication skill of our students. Communication skill should be improved by general education. Therefore, in order to develop a more effective overseas training program, we must reorganize the curriculum within the part of liberal arts subject. Through effective liberal arts lectures, students try to achieve the skills which have been mentioned above (A-F). They can overview that at each lecture different skills should be mastered.

2 H.S.U.H. has signed the Memorandum of Understanding (MoU) with 22 universities, dental faculties and medical institutions. The program sends $1-5$ students to each partner institution every March. 
Table 2. Liberal arts lectures related to overseas programs for first-sixth-year students and required English level of each lecture (third-year Overseas T/P, Overseas Medical Affairs and Academic English were newly set up by the liberal arts educational reform)

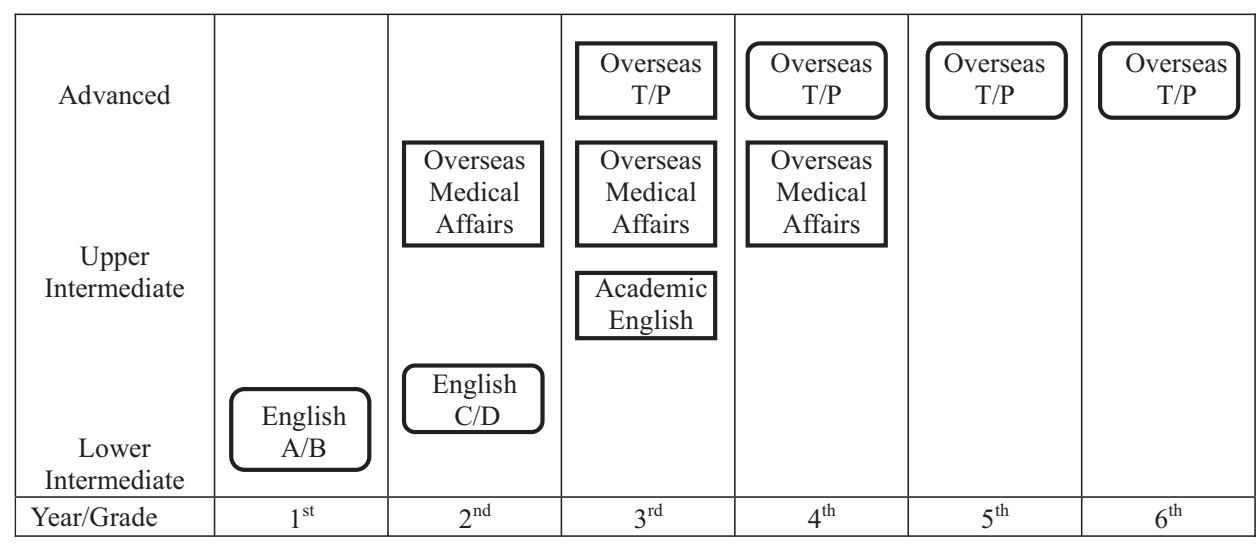

Source: Author's own study.

(a) "English A/B" for first-year students, "English C/D" for second-year students (compulsory course)

"English A/B" and "English $\mathrm{C} / \mathrm{D}$ "3 make students achieve basic reading, writing, and listening skills. Because these lectures are compulsory subjects, all students regardless of their motivation or English skill must take them. Therefore, in the classes there are students who have low language skills and are not always interested in international exchange and liberal arts subject. This is one of the reasons why it is hard to reform the lectures as a first step for overseas program. At least in the course "English B" and "English D", we teach how to read advanced academic texts, how to write logical and persuasive phrases and listen to audio materials from current news. This course aims at enhancing writing skills (D).

(b) "International relations" for first-year students (optional course)

"International relations" was newly founded by the reform and designed to promote unrestrained thinking of students and there is a sufficient number of hours for each participant to practice oral self-expression. The course is quite unique at our University in terms of subject which is not completely related to medical subjects and which frequently provides group activities. At the same

\footnotetext{
3 "English A" is the English-reading lecture in the first semester of the first year, "English B" - in the second semester of the first year, "English C" - in the first semester of the second year and "English D" - in the second semester of the second year.
} 
time, students achieve knowledge of political science, sociology, psychology, and anthropology. They also develop teamwork, leadership, presentation and discussion skills by debate, presentation and strategic games. This course aims at mastering the above-mentioned skills: (A), (B), (C), (D), (E), and (F).

(c) "Academic English" for third-year students (optional course)

"Academic English" was also newly founded by the reform and is one of the rare lectures that are conducted in English as a language of instruction. In this course, students master academic writing skills, presentation methods, and effective ways of self-presentation. Although the students have some difficulties with understanding all English expressions, no one has decided to give up the course so far. At the very end of the intensive course, students prepare the working paper and, based on it, they deliver a speech at a mock international conference which has discussants and the chair. This course aims at mastering the following skills: (A), (B), (C), and (D).

(d) "Overseas Medical Affairs" for second-, third-, and fourth-year students (optional course)

"Overseas Medical Affairs" was newly founded by the reform, too. It is another all-English lecture. All participants read textbooks concerning medical affairs and dental history and sum up the content. One of them delivers a short presentation and picks up disputable points from a particular chapter. Then, all participants join the discussion. One of the features of the course is the fact that it can be attended by students studying in different years. So, students can have a contact with other students who speak English fluently and are interested in international exchange through the lecture. This course aims at enhancing skills (A), (B), (C), (E) and (F).

(e) "Overseas Training A/B", "Overseas Practice A/B" for third-, fourth-, fifth-, and sixth-year students (optional course)

Before the reform, "English A/B", "English C/D", "Overseas Training and Practice" were not directly connected. This is the main reason why students could not use their English skills effectively. Newly founded lectures ("International relations", "Academic English" and "Overseas Medical Affairs") are expected to function as a bridge between already-existing lectures. It is advisable to enroll in "Overseas Training A/B" and "Overseas Practice A/B" after completing the above-mentioned lectures. The content and schedule of these lectures highly depend on our partner universities, so we cannot clearly indicate what kind of skills is demanded. What is important is to master discussion and presentation skills, 
which European and American University students have commonly trained in educational facilities. These courses constitute a great opportunity for students to have clinical practice abroad. By the current reform, third-year students can enroll this training and practice course. The goal of this course is to develop skills (A) and (E).

Table 3. Skills which should be achieved during courses

\begin{tabular}{|l|c|c|c|c|c|}
\hline & $\begin{array}{c}\text { "English } \\
\text { A /B/C/D" }\end{array}$ & $\begin{array}{c}\text { "Internatio- } \\
\text { nal relations" }\end{array}$ & $\begin{array}{c}\text { "Academic } \\
\text { English" }\end{array}$ & $\begin{array}{c}\text { "Overseas } \\
\text { Medical } \\
\text { Affairs" }\end{array}$ & $\begin{array}{c}\text { "Overseas } \\
\text { T/P" }\end{array}$ \\
\hline Communication & & $\checkmark$ & $\checkmark$ & $\checkmark$ & $\checkmark$ \\
\hline Presentation & & $\checkmark$ & $\checkmark$ & $\checkmark$ & \\
\hline Discussion & & $\checkmark$ & $\checkmark$ & $\checkmark$ & \\
\hline Grammar & $\checkmark$ & $\checkmark$ & $\checkmark$ & & \\
\hline $\begin{array}{l}\text { Leadership \& } \\
\text { teamwork }\end{array}$ & & $\checkmark$ & & $\checkmark$ & $\checkmark$ \\
\hline $\begin{array}{l}\text { Knowledge of } \\
\text { humanistic and } \\
\text { social sciences }\end{array}$ & & $\checkmark$ & & $\checkmark$ & \\
\hline
\end{tabular}

Source: Author's own study.

\section{H. Additional activities}

To implement the overseas training program more effectively, it is necessary for the University to provide the students with additional self-learning, promotion and support activities. Firstly, we should encourage additional self-learning of language among the students. As described above, it is unrealistic to master language attending the lecture once a week. Students should use long summer vacation more effectively. Without persistent learning, we cannot expect the improvement in terms of language skills. It is advisable to master one's skills by self-study at least 2-3 times a week for an hour at a time. Teaching staff must also emphasize the importance of self-study and recommend relevant textbooks for self-learners. Secondly, our University takes and keeps a close contact with partner universities to organize a more effective training program. One of the ideal forms is that students who master knowledge and skills in the above-mentioned lectures can directly use their achievements in particular programs of partner universities. If students feel that these trainings are useful, they will have more incentives to learn more. At the same time, university authorities should use reward systems to appreciate their students. 


\section{CONCLUSIONS}

In recent years, it is becoming apparent that young Japanese tend to prefer indoor activities and care very little about studying abroad. Health Sciences University of Hokkaido provides an attractive overseas program and specific training lectures for students who are interested in international exchange. This paper provided dental students' general expectations in terms of liberal arts education and overseas programs and the way University authorities should respond to such expectations by rearranging the existing lectures on non-dental subjects. The range of reform is quite limited, but there are still chances to improve it.

Being interested in foreign countries is one of the key driving forces to understand others and to acquire new knowledge and skills. If we start to be satisfied with current status, we cannot expect further development. Our University staff who have research experience in foreign countries are obliged to provide their students with some knowledge and skills. Teachers' personal overseas experience can also contribute to increasing the interest of students in foreign affairs.

Another essential issue in terms of making the current system more effective is the greater involvement of university staff in the reform of artistic education and international exchange. It should refer to all higher education institutions. The reform of English courses and of particular non-dental subjects is not enough to offer students a systematic process of gaining accomplishments and conducting activities across national boundaries. What is more, subjects, such as sociology, literature, philosophy, ethics, etc., effectively enhance students' personality and communication skills. Therefore, in order to complete perfect educational system, our teaching staff should exchange ideas and discuss how we should construct systematic educational programs to train professionals and restructure dental and non-dental subjects.

\section{REFERENCES}

Abe, K. (1997). What is "Kyōyō"? Tokyo (in Japanese).

Asogawa, S. (2015). Liberal Arts for Adult. Tokyo (in Japanese).

Bare, L.C., \& Dundes, L. (2004). Strategies for Combating Dental Anxiety. Journal of Dental Education, 68(11), 1172-1177.

Hiroshi, S. (2015). The True Value of Liberal Arts. Tokyo (in Japanese).

Karube, T. (2007). Changing Kyōyō. Tokyo (in Japanese).

Murakami, Y. (2004). Again, What is Kyōyō? Tokyo (in Japanese).

Nakajima, E., Tanabe, M., Morikawa, T., \& Kato, J. (2006). Considering the state of being of liberal arts education in faculties of medical science. Research Report of Seijo University (in Japanese). 
Recommendation of Liberal Arts. (2013). Tokyo (in Japanese).

Schwinn, D.A. (2016). Educate to transform: the art of developing curious minds. Transactions of the American Clinical and Climatological Association, 127. Retrieved from www.ncbi.nlm.nih.gov/pmc/articles/PMC5216474

Stratton, T.D., Elam, C.L., \& McGrath, M.G. (2003). A liberal arts education as preparation for medical school: How is it valued? How do graduates perform? Academic Medicine, 78(10), S59-S61, DOI: https://doi.org/10.1097/00001888-200310001-00019

Website of the Ministry of Health, Labour and Welfare (2018a). Retrieved from www. mhlw.go.jp/file/04-Houdouhappyou-11121000-Iyakushokuhinkyoku-Soumuka $/ 0000157906$.pdf\# search $=\% 27 \%$ E8\%96\%AC\%E5\%89\%A4\%E5\%B8\%A B+\%E5\%9B\%BD\%E5\%AE\%B6\%E8\%A9\%A6\%E9\%A 8\%93+\%Е5\%90\%88\%E6 $\% \mathrm{~A} 0 \% \mathrm{BC} \% \mathrm{E} 7 \% 8 \mathrm{E} \% 87 \% 27$

Website of the Ministry of Health, Labour and Welfare (2018b). Retrieved from www. mhlw.go.jp/stf/seisakunitsuite/bunya/0000085959.html

Website of Tokyo Medical and Dental University (2018). Retrieved from http://www.tmd. ac.jp/artsci/outline/las_aims.html

Why get a liberal education? It is the life and breath of medicine. (2016, 15 August). The Conversation. Retrieved from theconversation.com/why-get-a-liberal-education -it-is-the-life-and-breath-of-medicine-63898

Streszczenie: Edukacja w zakresie przedmiotów humanistycznych dla studentów medycyny i stomatologii zdaje się podupadać i jest to trend ogólnoświatowy. Jednym z głównych powodów tego stanu rzeczy jest fakt, że system edukacji w zakresie przedmiotów humanistycznych na wydziałach medycznych i stomatologicznych nie zawsze potrafi dostosować się do zmieniających się potrzeb społecznych, a studenci nie odczuwają konieczności doskonalenia się w zakresie przedmiotów humanistycznych. W niniejszym artykule, na przykładzie Wydziału Stomatologicznego Uniwersytetu Nauk Medycznych Hokkaido, autor przeprowadził analizę najbardziej idealnej koncepcji edukacji humanistycznej w obecnym czasie oraz opisał propozycję działań reformatorskich w zakresie tej edukacji na uczelniach o profilu medyczno-stomatologicznym.

Słowa kluczowe: nauki humanistyczne; edukacja w zakresie języka angielskiego; Japonia; wydział stomatologiczny; umiejętności (kompetencje) miękkie 